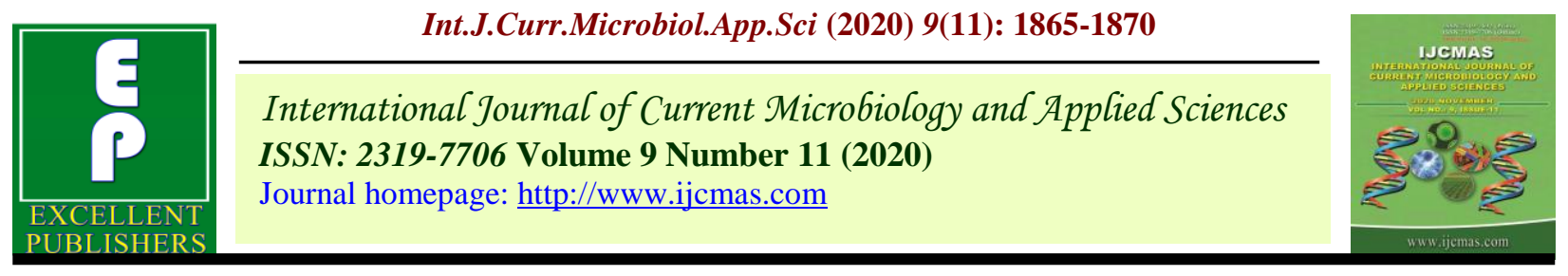

Original Research Article

https://doi.org/10.20546/ijcmas.2020.911.220

\title{
Genetic Variability Analysis in Ashwagandha [Withania somnifera (L.) Dunal]
}

\author{
Deeksha Chauhan*, R. B. Dubey, Jagdish Prasad and Suverchala Bommana Reddy \\ ${ }^{1}$ Deptt. of Genetics and Plant Breeding, RCA, MPUAT, Udaipur, India \\ *Corresponding author
}

\section{A B S T R A C T}

\begin{tabular}{|l|}
\hline K e y w o r d s \\
Ashwagandha, \\
Genetic variability, \\
GCV, PCV, \\
Heritability, \\
Genetic advance \\
\hline Article Info \\
\hline Accepted: \\
15 October 2020 \\
Available Online: \\
10 November 2020 \\
\hline
\end{tabular}

The Present investigation was carried out using 75 genotypes along with two standard checks viz; JA-20 (Jawahar Asgandh-20) and JA-134 (Jawahar Asgandh-134). The examination was spread out in Augmented RBD design during Kharif 2019 at the Instructional Farm, Rajasthan College of Agriculture, Udaipur. Sufficient variability was present in the genotypes under study for all the characters indicating sufficient genetic variability among the genotypes. Highest GCV was found for secondary branches (33.04), primary branches (26.36) and fresh plant weight (20.26) where as lowest GCV was observed in the character days to $75 \%$ maturity (0.45). Highest PCV was found for Secondary branches (34.44), primary branches (29.90), root diameter (21.03) and fresh plant weight (20.28) where as lowest PCV was observed in days to $75 \%$ maturity (1.38). The high estimates of heritability values noticed in characters like Fresh plant weight (99.85), plant height (99.35), and days to flowering (97.64). High heritability with high genetic advance was found in fresh plant weight per plant. High heritability together with high genetic advance was observed for fresh plant weight. The genetic advance was found high $(>20 \%)$ in the character fresh plant weight $(41.38 \%)$.

\section{Introduction}

Ashwagandha [Withania somnifera $(\mathrm{L}$. Dunal] generally known as Indian ginseng is likewise named poison gooseberry or winter cherry (Deshpande, 2005). Ashwagandha is an angiosperm plant that belongs to the Solanaceae family (Mir et al., 2013). It is a self-pollinated plant bearing chromosome no. 2n=48 (Nigam et al., 1995; Das et al., 2009), 2n=24 (Ram and Kamini, 1964), $2 \mathrm{n}=75$ (Bir and Neelam, 1980). It is hardy and drought-tolerant perennial plant (Ali et al., 1997) that develops well in dry and sub- tropical regions having well-drained, sandy loam or light red soils (Kukreti et al., 2013) having $\mathrm{pH}$ of 7.5 to 8.0 with an average rainfall of $600-750 \mathrm{~mm}$. Two species of Ashwagandha are found in India, viz. Withania sornnifera (L.) Dunal (Ashwagandha) and Withania coagulans (L.) Dunal (Panir). A few reports uncovered that alkaloid content found in Indian root ranges between 0.13 to 0.66 which is lower than 4.3 percent found at places other than India. Ashwagandha is native of North-western and Central India as well as the Mediterranean region of North Africa. It tends to be 
developed over a wide scope of locales stretching out from $23^{0} \mathrm{~N}$ to $33^{0} \mathrm{~N}$ latitude and from $18-170 \mathrm{~m}$ altitude above sea level, including the states of Maharashtra, Madhya Pradesh, Gujarat, Rajasthan, Uttar Pradesh, Haryana, Punjab, Orissa, Sikkim and Assam (Billore, 1989; Chaudhari and Vacharajani, 1992; Pandey and Dixit, 1980). Root is the most significant part of the entire plant as it possesses a wide scope of therapeutic agents and its therapeutic utility is due to the presence of alkaloids, essentially Withanolides (Devi et al., 1993). Assessment of variability in available germplasm is the most important as well as the initial step of any breeding programme. More noteworthy the variability in the genetic material more odds of genetic improvement. Estimation of genotypic coefficient of variation (GCV) and phenotypic coefficient of variation (PCV) helps to choose the potential genotype and heritability along with genetic advance would be more useful tool in predicting the resultant effect for selection of best genotypes for yield. Keeping these things in the view, the present investigation were made to assess genotypes with the objectives, to estimate the variability, coefficients of variability and the genetic parameters, viz. heritability, expected genetic advance (standard), and genetic gain along side the mean and range of different characters in the current examination.

\section{Materials and Methods}

The diverse genotypes were collected from Herbal Park, RCA (UDAIPUR). Topographically, Udaipur is situated at $24^{\circ}$ $35^{\circ} \mathrm{N}$ scope and $73^{0}-42^{0} \mathrm{E}$ longitude and at a rise of 582.17 meters above mean sea level. Field explore was led to get the genetic variability among 75 genotypes with two standard checks viz; JA-20 and JA-134 were evaluated in Augmented RBD design. The sound yield seeds of every genotype were planted in single plot of 3 meter length keeping up crop geometry $30 \times 5 \mathrm{~cm}$ row to row and plant to plant spacing respectively at Instructional Farm, Rajasthan College of Agriculture, MPUAT, Udaipur, during Kharif 2019. The recommended package of practices was adopted for raising the healthy crop. Observations were recorded for eleven characters on ten randomly selected competitive plants for each genotype except some of the characters which were recorded on whole plot basis.

\section{Statistical analysis}

To test the difference among the genotypes, the analysis of variance was worked out separately for each character as per method suggested by fisher (1954) and using standard statistical procedure given by Panse and Sukhatme (1954). Genotypic coefficient of variation $(\mathrm{GCV})$ and Phenotypic coefficient of variation (PCV) were calculated as per the standard formula suggested by Burton (1952).

\section{Genotypic coefficient of variation (GCV)}

It was calculated using the following formula as suggested by the Burton (1952).

$\mathrm{GCV}=\frac{\sqrt{\mathrm{V}_{\mathrm{g}}}}{\overline{\mathrm{X}}} \times 100$

Where,

$\mathrm{V}_{\mathrm{g}}=$ Genotypic variance

$\overline{\mathrm{X}}=$ Population mean

\section{Phenotypic coefficient of variation (PCV)}

It was calculated using the following formula as suggested by Burton (1952).

$\mathrm{PCV}=\frac{\sqrt{\mathrm{V}_{\mathrm{p}}}}{\overline{\mathrm{X}}} \times 100$ 
Where,

$\mathrm{V}_{\mathrm{p}}=$ phenotypic variance

$\overline{\mathrm{X}}=$ Population mean

\section{Heritability in Broad sense $\left(\mathrm{h}^{2}{ }_{\mathrm{BS}}\right)$}

It was computed using the following formula stated by Burton and De vane (1953) and Hanson et al., (1956).

$\mathrm{h}_{\mathrm{bs}}^{2}(\%)=\frac{\mathrm{V}_{\mathrm{g}}}{\mathrm{V}_{\mathrm{p}}} \times 100$

Where,

$\mathrm{V}_{\mathrm{g}}=$ genotypic variance

$\mathrm{V}_{\mathrm{p}}=$ phenotypic variance

$\mathrm{h}^{2}{ }_{\mathrm{bs}}=$ broad sense heritability.

GA $=$ Genetic advance $=\frac{K \cdot v_{g}}{\sqrt{v_{p}}}$

Where,

$\mathrm{Vg}=$ Genotypic variance

$V_{p}=$ Phenotypic variance

$\mathrm{K}=$ Selection differential at 5 per cent selection pressure i.e. 2.06

\section{Genetic gain}

It is percent expected genetic advance over the population mean. It was computed as follows using the formula of Johnson et al., (1955)

$\mathrm{GG}=\frac{\mathrm{GA}}{\bar{x}} \times 100$

Where,

$\overline{\mathrm{X}}=$ Population mean

\section{Results and Discussion}

The maximum dry root yield exhibited by the PWS-6 (3.20 g) followed by UWS-89 (3.10), PWS-27 (2.90) and UWS-83 (2.86). The magnitude of GCV varied from 0.45 percent in days to 75 percent maturity to 33.04 percent in secondary branches. It was found that GCV was found low $(<10 \%)$ for the characters days to flowering (2.24\%), days to maturity $(0.45 \%)$, dry root yield $(7.14 \%)$. The GCV was moderate (10-20\%) for plant height $(13.33 \%)$, root length $(14.71 \%)$ root diameter (19.68\%), fresh root yield (17.73\%), alkaloid content $(10.97 \%)$ and for primary branches (26.36\%), secondary branches (33.04\%), fresh plant weight $(20.26 \%)$, the GCV was found high (>20\%). The present findings are In accordance with the findings of Kumar et al., (2007), Yadav et al., (2008), Sangwan et al., (2013), Sundesha and Tank (2013), Joshi et al., (2014), Singh et al., (2014) and Dev et al., (2015). It was found that PCV was found low $(<10 \%)$ for the characters days to flowering $(2.27 \%)$, days to maturity $(1.38 \%)$. The PCV was moderate (10-20\%) for Plant height (13.37\%), root length (15.02\%), Fresh root yield $(18.35 \%)$, dry root yield $(18.73 \%)$ and alkaloid content (11.65\%). The PCV was found high $(>20 \%)$ for primary branches (29.90\%), secondary branches (34.44\%), fresh plant weight (20.28\%) and root diameter $(21.03 \%)$. The present findings are In accordance with the findings of Kumar et al., (2007), Yadav et al., (2008), Sangwan et al., (2013), Sundesha and Tank (2013), Joshi et al., (2014), Singh et al., (2014) and Dev et al., (2015). The high estimates of heritability values noticed in characters like Fresh plant weight (99.85), plant height (99.35), days to flowering (97.64). High heritability with high genetic advance was found in fresh plant weight per plant. High heritability together with high genetic advance was observed for fresh plant weight (Table 1 and 2). 
Table.1 ANOVA for augmented RBD design

\begin{tabular}{|l|l|c|c|c|c|c|c|}
\hline SN & Character & Block & Treatment & Check & Germplasm & C v/s G & Error \\
\hline & & {$[4]$} & {$[76]$} & {$[1]$} & {$[74]$} & {$[1]$} & {$[4]$} \\
\hline 1. & Days to flowering & $1.20^{*}$ & $5.38^{* *}$ & $8.06^{* *}$ & $5.41^{* *}$ & 0.01 & 0.13 \\
\hline 2. & Days to 75\% maturity & 4.00 & 5.65 & 4.90 & 5.48 & 18.47 & 4.90 \\
\hline 3. & Plant height(cm) & $1.33^{* *}$ & $9.68^{* *}$ & $6.96^{* *}$ & $8.48^{* *}$ & $101.29 * *$ & 0.06 \\
\hline 4. & Primary branches & 0.24 & 1.20 & 1.10 & 1.13 & $6.31^{* *}$ & 0.25 \\
\hline $\mathbf{5 .}$ & Secondary branches & 0.43 & $4.37^{*}$ & 0.00 & $4.48^{*}$ & 0.00 & 0.36 \\
\hline 6. & Root length(cm) & 0.78 & $7.13^{* *}$ & $33.60 * *$ & $6.79^{* *}$ & $5.82^{*}$ & 0.28 \\
\hline 7. & Root diameter(mm) & 0.68 & $1.81^{*}$ & 0.71 & $1.85^{*}$ & 0.15 & 0.23 \\
\hline 8. & Fresh root yield (g) & 2.16 & $6.63 *$ & $15.20 * *$ & $6.52^{*}$ & $6.40^{*}$ & 0.43 \\
\hline 9. & Dry root yield (g) & 0.04 & 0.18 & 0.01 & 0.18 & 0.02 & 0.16 \\
\hline $\mathbf{1 0 .}$ & Fresh plant weight (g) & $6.74 *$ & $462.97^{* *}$ & $43.43^{* *}$ & $404.76^{* *}$ & $5190.61 * *$ & 0.59 \\
\hline $\mathbf{1 1}$ & Alkaloid content (\%) & 0.00 & $0.00^{*}$ & $0.00^{*}$ & $0.00^{*}$ & 0.00 & 0.00 \\
\hline
\end{tabular}

$*$ and $* *$ indicates significant level at $5 \%$ and $1 \%$ respectively. [ ] Degrees of freedom.

Table.2 Genetic variability parameters of different characters in ashwagandha

\begin{tabular}{|l|l|r|r|r|r|r|}
\hline $\mathbf{S N}$ & Character & GCV & PCV & \multicolumn{1}{|c|}{$\mathbf{H}^{\mathbf{2}}$} & \multicolumn{1}{|c|}{ GA } & \multicolumn{1}{|c|}{ GG } \\
\hline $\mathbf{1}$ & Days to flowering & 2.24 & 2.27 & 97.64 & 4.68 & 4.57 \\
\hline $\mathbf{2}$ & Days to 75\% maturity & 0.45 & 1.38 & 10.64 & 0.51 & 0.30 \\
\hline $\mathbf{3}$ & Plant height(cm) & 13.33 & 13.37 & 99.35 & 5.96 & 27.37 \\
\hline $\mathbf{4}$ & Primary branches & 26.36 & 29.90 & 77.75 & 1.70 & 47.88 \\
\hline $\mathbf{5}$ & Secondary branches & 33.04 & 34.44 & 92.01 & 4.01 & 65.28 \\
\hline $\mathbf{6}$ & Root length(cm) & 14.71 & 15.02 & 95.89 & 5.15 & 29.67 \\
\hline $\mathbf{7}$ & Root diameter(mm) & 19.68 & 21.03 & 87.60 & 2.45 & 37.94 \\
\hline $\mathbf{8}$ & Fresh root yield (g) & 17.73 & 18.35 & 93.34 & 4.91 & 35.28 \\
\hline $\mathbf{9}$ & Dry root yield(g) & 7.14 & 18.73 & 14.53 & 0.13 & 5.61 \\
\hline $\mathbf{1 0}$ & Fresh plant weight(g) & 20.26 & 20.28 & 99.85 & 41.38 & 41.71 \\
\hline $\mathbf{1 1}$ & Alkaloid content $(\%)$ & 10.97 & 11.65 & 88.67 & 0.07 & 21.27 \\
\hline
\end{tabular}

GCV-Genotypic coefficient of variation, PCV-Phenotypic coefficient of variation, $\mathrm{h}^{2}$-Heritability, GG-Genetic Gain 
Similar findings have also been reported by Mohsina and Dutta (2007), Dubey (2010), Sangwan et al., (2013), Joshi et al., (2014), Singh et al., (2014), Dev et al., (2015), Gami et al., (2015). The genetic advance was found high $(>20 \%)$ in the character fresh plant weight $(41.38 \%)$. Similar findings have also been reported by Mohsina and Dutta (2007), Sangwan et al., (2013), Nagar (2018).

The phenotypic coefficient of variation was higher in magnitude than the respective genotypic coefficient of variation for all the characters. The phenotypic coefficient of variation estimate was generally higher than genotypic coefficient of variation estimates indicating positive effect of environment on character expression. High heritability together with high genetic advance was observed for fresh plant weight. Panse (1957) reported that high heritability together with high genetic advance was indicative of additive gene effects and high heritability associated with low genetic advance was indication of dominance and epistatic effects.

\section{References}

Ali, M., Shuaib, M. and Ansari, S.H. 1997. Withanolides from the stem bark of Withania somnifera. Phytochemistry, 44: 1163-1168.

Billore, K.V. 1989. Some threatened medicinal plants of Rajasthan and their conservation. Indian Forester, 15: 595599.

Bir, S.S. and Neelam, J. 1980. Chromosome number reports LXIX. Taxon. 29: 703730 .

Burton, G.W. 1952. Quantitative Inheritance in Grasses. Proceedings of sixth International Grassland Congress. 1: 277-288.

Chaudhari, B.G. and Vacharajani. 1992. Important medicinal weeds plants of Gujarat- A source of raw material for pharmaceutical industries. Bull. Med. Ethno. Bot. Res., 13: 65-73.

Das, A., Datta, A. K. and Ghose, S. 2009. Cytogenetical studies on two varieties of Withania somnifera. Journal of Tropical Medicinal Plants, 10: 249-256.

Deshpande, D.J. 2005. Commercial cultivation of medicinal and aromatic plants. Himalaya Publishing house, 203206.

Devi, P.U., Sharada, A.C. and Solomon, F.E. 1993. Antitumor and radiosensitizing effects of Withania somnifer $\underline{a}$ (Ashwagandha) on a transplantable mouse tumor, Sarcoma-180. Indian J ExpBiol, 31: 607-11.

Dev, S., Dubey, R.B. and Ameta, K.D. 2015. Studies on variability and character association in Ashwagandha [Withania somnifera (L.) Dunal]. Progressive Horticulture, 47(1):154- 157.

Dubey, R. B. 2010. Genetic variability, correlation and path analysis in Ashwagandha [Withania somnifera (L.) Dunal]. Journal of Medicinal and Aromatic Plant Sciences, 32(3): 202205.

Fisher, R.A. 1954. Statistical Methods for Research Workers. Biological Monograph and Manuals, 5: 130-131.

Gami, R.A., Solanki, S.D., Patel, M.P., Tiwari, K., Bhadauria, H.S. and Kumar, M. 2015. International Journal of Agricultural Science and Research (IJASR), 5(5): 271-276.

Hanson, C.H., Robinson, H.F. and Comstock, R.E. 1956. Biometrical studies on yield in segregating populations of Korean lespedza. Agronomy Journal, 48:268272.

Johnson, H.W., Robinson, H.F. and Comstock, R.F. 1955. Estimation of genetic environmental variability in soybean. Agronomy Journal, 47: 314318.

Joshi, N.R., Patel, M.A., Prajapati, K.N. and 
Patel, A.D. 2014. Genetic variability, correlation and path analysis in ashwagandha [Withania somnifera (L.) Dunal]. Electronic Journal of Plant Breeding, 5(4): 875-880.

Kukreti, C., Rajwar, G.S. and Uniyal, P.L. 2013. Effect of growth regulators on growth and yield of ashwagandha Withania somnifera (L.) Dunal. Medicinal plant, 5(2): 66-70.

Kumar, A., Kaul, M. K., Bhan, M. K., Khanna, P.K. and Suri, K. A. 2007. Morphological and chemical variation in 25 collections of the Indian medicinal plant, Withania somnifera (L.) Dunal (Solanaceae). Genet Resour Crop Evol, 54: 655-660.

Mir, B. A., Koul, S. and Soodan, A. S. 2013. Reproductive biology of Withania (Ashwagandha) sp. novo (Solanaceae), 45: 442- 446.

Mohsina, I. and Dutta, A.K. 2007. Genetic variability, correlation and path analysis in ashwagandha [Withania somnifera (L.) Dunal]. Journal of Phytological Research, 20(1):119-122.

Nagar, K. 2018. Studies on genetic divergence in ashwagandha [Withania somnifera (L.) Dunal]. M.Sc. thesis submitted to Rajasthan College of Agriculture, MPUAT, Udaipur.

Nigam, K.B. and Kandalkar, V.S. 1995. Ashwagandha - Advances in horticulture, medicinal and Aromatic plants. Malhorta Publishing House, New Delhi, India, 11: 337-344.

Pandey, H.C. and Dixit, R.S. 1980. Prospects of cultivation of medicinal plants in
Bundelkhand division (Uttar Pradesh) Nagarjun, 24: 33-37.

Panse, V.G. (1957). Genetics of quantitative characters in relation to plant breeding. Indian Journal of Genetics. 17: 318328.

Panse, V.G. and Sukhatme, P.V. 1985. Statistical methods for agricultural workers, ICAR Publication, New Delhi.

Ram, H.Y.M. and Kamini, I. 1964. Embryology and fruit development in Withania somnifera (L.) Dunal, Phytomorphology, 14: 574-587.

Sangwan, O., Avtar, R. and Singh, A. 2013. Genetic variability, character association and path analysis in ashwagandha [Withania somnifera (L.) Dunal] under rainfed conditions. Research in Plant Biology, 3(2): 32-36.

Singh, A.K., Tirkey, A. and Nagvanshi, D. 2014. Study of genetic divergence in ashwagandha (Withania somnifera (L.) Dunal). International Journal of Basic and Applied Biology (IJBAB), 2(1): 511.

Sundesha, D. L. and Tank, C. J. 2013. Genetic variability, heritability, expected genetic gain for dry root yield in Ashwagandha [Withania somnifera (L.) Dunal]. Asian Journal of Horticulture, (8)2: 475-477.

Yadav, O. P.; Kumar, Y. and Verma, P. K. (2008). Genetic variability, association among metric traits and path coefficient analysis in Ashwagandha (Withania somnifera). Haryana Agriculture University Journal of Research. 38(1/2): 23-26.

\section{How to cite this article:}

Deeksha Chauhan, R. B. Dubey, Jagdish Prasad and Suverchala Bommana Reddy. 2020. Genetic Variability Analysis in Ashwagandha [Withania somnifera (L.) Dunal]. Int.J.Curr.Microbiol.App.Sci. 9(11): 1865-1870. doi: https://doi.org/10.20546/ijcmas.2020.911.220 